\title{
Cascade-pond System Health Assessment Based on Macroinvertebrate Indices and Its Relationship with Impervious Cover and Aquatic Buffer Zone in Urbanized Catchments
}

\author{
Faris Zulkarnain ${ }^{1,2 *}$, Dwita Sutjiningsih ${ }^{1}$, and Yasman ${ }^{3}$ \\ ${ }^{1}$ Department of Civil Engineering, Faculty of Engineering, Universitas Indonesia, Indonesia \\ ${ }^{2}$ Center for Applied Geography Research, Universitas Indonesia, Indonesia \\ ${ }^{3}$ Department of Biology, Faculty of Mathematics \& Natural Science, Universitas Indonesia, Indonesia
}

\begin{abstract}
A cascade-pond system consists of six ponds located at Universitas Indonesia Campus, Depok. Its catchment area is dominated by high density urban area with moderate to high imperviousness. Some of riparian buffers surrounds six ponds are also occupied by high imperviousness that may lead some ecohydrological problems i.e. water quality degradation, declining freshwater biodiversity and food web changes. The aim of this study is assessing the current state of cascadepond system health. The assessment of macroinvertebrate indices is based on SingScore that have been developed by Public Utilities Board of Singapore for macroinvertebrate biotic index. Impervious cover data is obtained from high-resolution imageries and processed using ArcGIS 10.5. Qualitative statistics methods, Chi-squared test describes the relationship of macroinvertebrate indices with catchment area imperviousness and aquatic buffer zone. The health assessment based on macroinvertebrates indices shows that the lower ponds are relatively healthier than the upper one. There is also any significant relationship between macroinvertebrate indices with impervious cover based on chi square test and cross tabulation analysis.
\end{abstract}

\section{Introduction}

A cascade-pond system consists of six ponds located at Universitas Indonesia (UI) campus, Depok. Its catchment namely UI catchment, as a part of Ci Liwung watershed is dominated by urbanized area with high imperviousness. Previous studies found that UI catchment has varied imperviousness, from $22 \%$ to $76.9 \%$ [1]. According to Center for Watershed Protection, current state of imperviousness in UI catchment is classified from impacted to heavily damaged for its stream health [2]. High imperviousness would lead some

${ }^{*}$ Corresponding author: faris.zulkarnain@sci.ui.ac.id 
ecohydrological problems for 6 ponds at UI catchment i.e. water quality degradation, aquatic habitat destruction, declining freshwater biodiversity, etc $[1,3,4,5]$.

Macroinvertebrate indices believed as one of bioindicator tools to assess the current state of freshwater environment in catchment scale $[6,7,8,9,10]$. There are many advantages of macroinvertebrate as bioindicator i.e. their relatively easy to collect and identify, their low mobility, their high sensitivity for several environmental parameter changes, found in almost freshwater environment both lakes or stream, and their numerical abundance $[11,12,13]$. Macroinvertebrate also has important roles for aquatic ecosystem. They act as first consumers in aquatic food webs and play a role in the process of recycling nutrients $[14,15,16]$.

Macroinvertebrates indices is being used widely in the world, from subtropics to tropics region. In the Southeast Asia region, Public Utilities (PUB) of Singapore developed The Singscore as macroinvertebrate biotic indices to assess the aquatic environment health [17]. This study is using SingScore to calculate the macroinvertebrate indices, assumes that geographical, meteorology, climatology, and indigenous macroinvertebrates are quite similar between Singapore and Indonesia.

Macroinvertebrate indices would be varied spatially. Previous studies show that there is any relationship between macroinvertebrate indices and impervious cover. If the percentage of impervious cover is high, then the macroinvertebrate indices score would be low $[18,19,20]$. Besides impervious cover, aquatic buffer zone is also influencing macroinvertebrate indices [21]. High score indices would be associated with high riparian cover buffer zone. Reducing riparian buffer zone would altered the macroinvertebrate indices [22,23]. On the other hands, impervious cover area buffer zone would affect macroinvertebrate indices badly.

The objectives of this research are applying the macroinvertebrate indices that developed by Public Utilities Board of Singapore namely SingScore and determining the relationship between macroinvertebrate indices and many environmental variables, which the most significant environmental variables that affecting the macroinvertebrate indices. Many research has been conducted to determine the relationship between macroinvertebrate indices but mostly in lentic ecosystem. Until now, there is only a few research about macroinvertebrate indices in pond or lotic ecosystem particularly cascade-pond system.

\section{Materials and Methods}

\subsection{Study Site}

This study was conducted at UI catchment area that located at the boundary of Jakarta Special Capital Region and Depok City, West Java, Indonesia. UI catchment consists of 6 catchments. (see Figure 1). The upper part of UI catchment area which is A1 and A2 subcatchment has the highest percentage of impervious cover than the lower part (see Table 1). Land use in the lower part of UI catchment area are dominantly vegetation cover (see Figure 1). The total area of UI catchment area is approximately 580 hectares where around 305 hectares is located inside the UI Campus and 275 hectares is located at the southern of UI Campus. The UI Campus was well designed with a suitable landscape to maintain the natural condition of topography, water bodies, natural vegetation, and indigenous organism. On the other hand, the outside of the campus is dominated by unwell planned, high density, and fast growing residential area [1]. 


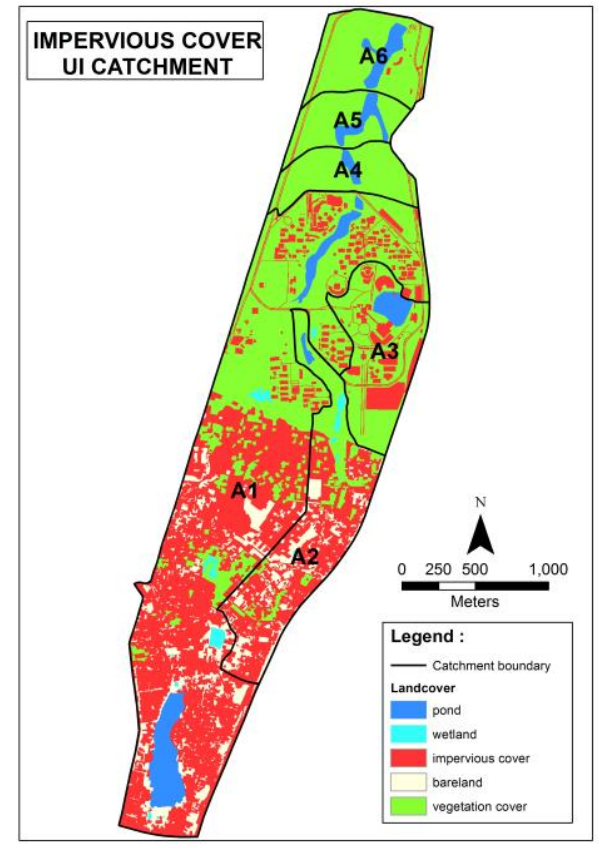

Fig. 1. Impervious cover map of Universitas Indonesia catchment

Four of six catchments in Universitas Indonesia are classified as non-supporting for its stream health while the others classified as heavily damaged and impacted [2]. Each catchment has one pond except A1 catchment. A1 catchment has two ponds namely Rawa Besar pond and Kenanga pond. In this study, Rawa Besar pond is not included for further analysis because it is not included as the cascade-pond system.

UI catchments cascade-pond system has 6 stormwater ponds, known for its acronym KAMPUS (Kenanga-Agatis-Mahoni-Puspa-Ulin-Salam). All of this ponds was built in 1990's. The function of cascade-pond system at UI campus is built firstly for capturing and storing storm water runoff temporarily or for some periods of time. Cascade-pond system is also known as the "end-of-pipe" term to maintain water quality and/or quantity impacts from upper part of catchment [24].

Table 1. Subcatchment Imperviousness.

\begin{tabular}{|c|c|c|c|}
\hline Catchment Code & Pond (Point of Interest) & Imperviousness & Classification \\
\hline A1 & Mahoni & $44.20 \%$ & Non-supporting \\
\hline A2 & Agathis & $76.90 \%$ & Heavily damaged \\
\hline A3 & Kenanga & $22.40 \%$ & Impacted \\
\hline A4 & Puspa & $41.50 \%$ & Non-supporting \\
\hline A5 & Ulin & $39.30 \%$ & Non-supporting \\
\hline A6 & Salam & $36.20 \%$ & Non-supporting \\
\hline
\end{tabular}




\subsection{Sampling methods}

Field sampling was carried out at six ponds. All ponds were divided into three stations which is inlet, middle, and outlet. All macroinvertebrates samples were taken from January to March 2017 within two replicate during the rainy season using a standard $1 \mathrm{~mm}$ mesh hand net. All samples were randomly caught from each substrate habitat i.e. riprap, clay, vegetation, and mud. After being caught, samples preserved with $4 \%$ formaldehyde, then identified using microscope.

\subsection{Macroinvertebrate Indices}

Macroinvertebrates were identified to family level. Identification of macroinvertebrates based on [17]. After the process of identification, macroinvertebrates were calculated using SingScore that developed by Public Utilities Board of Singapore. SingScore gives varied tolerance score for each family level of macroinvertebrates. The range score is from 1 to 10 that the smaller score indicates the most tolerant family and vice versa. The SingScore then were classified from 1-10 tolerance score into three classification: 1-3 is tolerant, 4-6 is moderate, and 7-10 is sensitive (see Table 3). The tolerant classification indicates that the pond has poor water quality while the sensitive classification indicates has good water quality [17]. The overall tolerance score of Singscore is shown below:

$$
\text { Singscore }=\frac{\sum_{i=1}^{i=S} a_{i}}{S} \times 20
$$

Where $\mathrm{S}=$ the total number of taxa in the sample and $\mathrm{a}_{\mathrm{i}}$ is telorance value for the $\mathrm{i}^{\text {th }}$ taxon. The classification of macroinvertebrate indices for water quality assessment are as follows:

Table 2. SingScore Classification [26]

\begin{tabular}{|c|c|}
\hline SingScore & Likely Water Quality \\
\hline $0-79$ & Poor \\
\hline $80-99$ & Fair \\
\hline $100-119$ & Good \\
\hline$>120$ & Excellent \\
\hline
\end{tabular}

\subsection{Impervious Cover and Aquatic Buffer Zone Estimation}

Estimation of catchment area imperviousness and aquatic buffer zone were generated by applying GIS technology [1]. This study using ArcGIS 10.5 software and digitized the impervious cover feature (rooftops, asphalt road, concrete road) from high resolution imagery by visual interpretation method. The classification of impervious cover is based on Center for Watershed Protection [2]. Aquatic buffer zone is divided into three categories i.e.: high density forest, forest, and built-up area. The distance of aquatic buffer zone is 50 meters from ponds.

Qualitatively statistics method, chi squared test and cross tabulation options was used to investigate the relationship between macroinvertebrate indices with impervious cover and aquatic buffer zone. Macroinvertebrate indices becomes dependent variable and impervious cover and aquatic buffer zone acts as independent variables. Chi squared test was executed using IBM $^{\circledR}$ SPSS $^{\circledR}$ statistics version 22. 


\section{Results and Discussions}

\subsection{Macroinvertebrate Indices at 5 Ponds}

The percentage of macroinvertebrate indices that found in cascade-pond system of UI catchment is shown below:

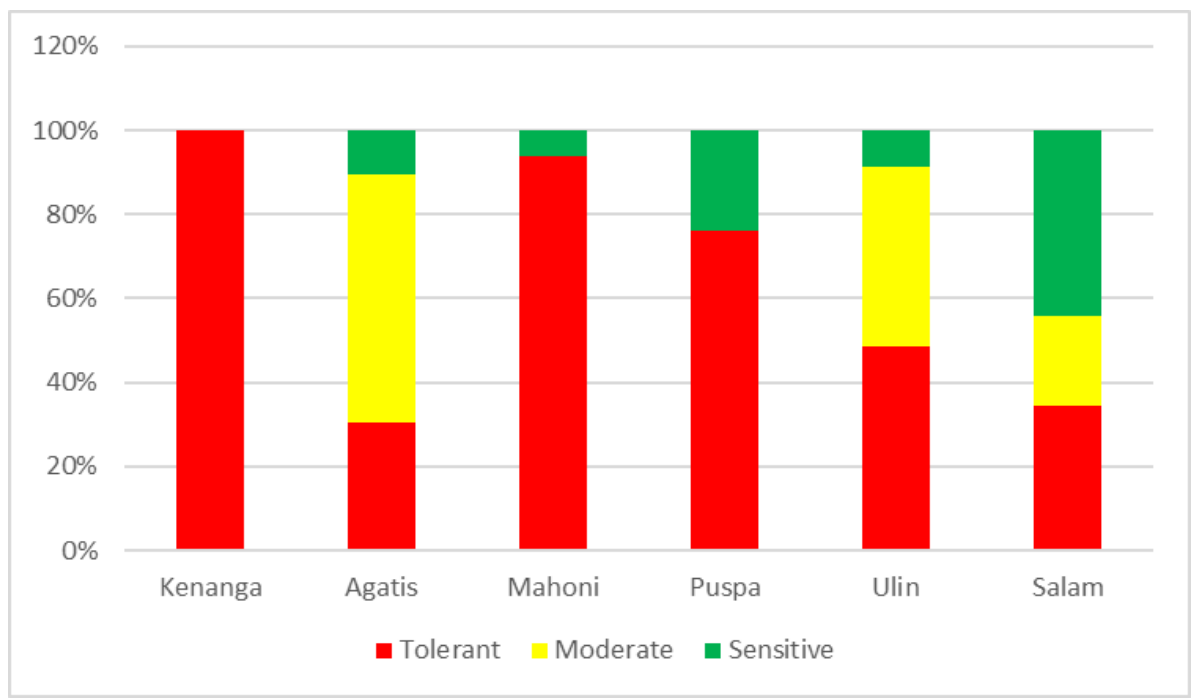

Fig. 2. Percentage of Macroinvertebrates

Water quality in Kenanga pond, the upper of cascade-pond system is poor with overall score 26 because $100 \%$ of macroinvertebrates that have been collected is classified as tolerant. The other upper cascade-pond system, Agatis pond is better than Kenanga pond because the moderate macroinvertebrates was dominating rather than tolerant macroinvertebrates. It was also found low percentage of sensitive macroinvertebrates at Agatis pond. The overall macroinvertebrates indices score of Agatis is 101, classified as good water quality. Mahoni pond that located after Agatis pond, classified as poor with high percentage of tolerant macroinvertebrates and very low percentage of sensitive macroinvertebrates. The overall score for Mahoni pond is 58, classified as poor water quality. The middle part of cascade pond system, Puspa pond is also quite similar with Mahoni pond although the overall score is slightly increasing after Mahoni pond but still classified as poor water quality. The lower pond, Ulin pond is relatively better than Mahoni pond and Puspa pond which located in the upper of Ulin pond.

Table 3. Macroinvertebrates Indices Score

\begin{tabular}{|c|c|c|c|c|c|c|}
\hline \multirow{2}{*}{ Score } & \multicolumn{7}{|c|}{ Cascade-Pond System } \\
\cline { 2 - 7 } & Kenanga & Agathis & Mahoni & Puspa & Ulin & Salam \\
\hline Singscore & 26 & 101 & 58 & 75 & 86 & 113 \\
\hline Likely Water Quality & Poor & Good & Poor & Poor & Fair & Good \\
\hline
\end{tabular}


The "end-of-pipe" of cascade-pond system which is Salam pond has the best water quality condition based on macroinvertebrate indices. The percentage of sensitive macroinvertebrate is dominant, it makes the overall score of Salam pond is the highest (see Table 3).

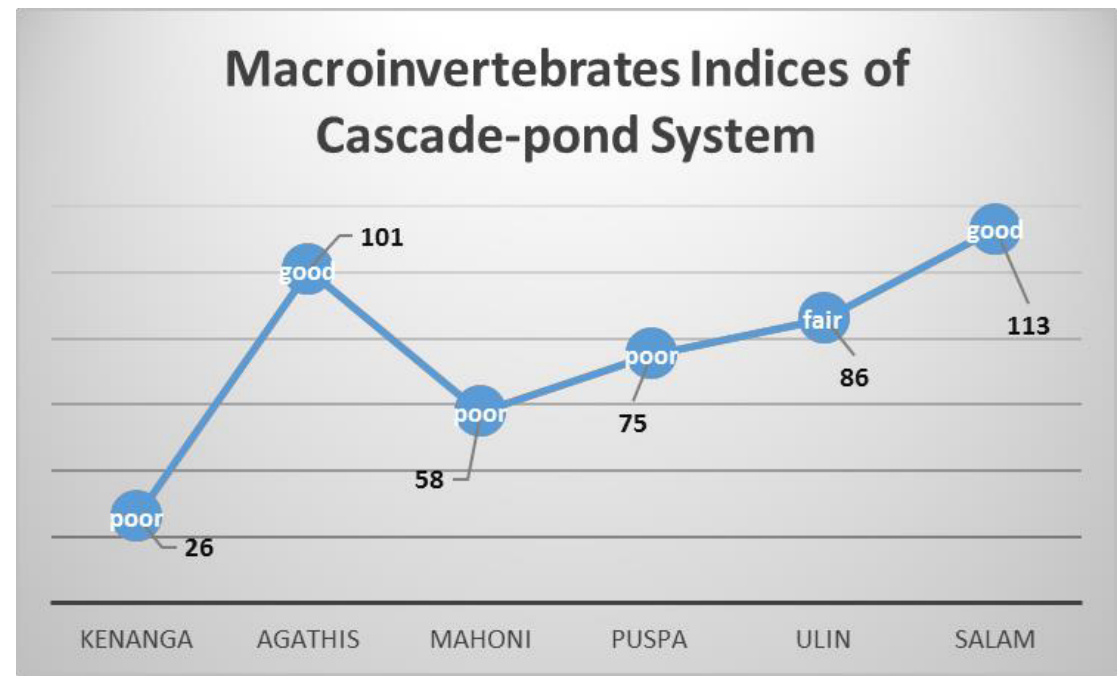

Fig. 3. Macroinvertebrates Indices of Cascade-pond System

Viewing all of the pond into a whole cascade-pond system, the distribution of macroinvertebrates indices is getting better and healthier from upstream to downstream but there is unique evidence in the upper ponds. Kenanga pond and Agatis pond that both located in the upper of catchment has big different scores and water quality classification. This different score between Kenanga pond and Agatis pond might be influenced by impervious cover $[18,19,20,22,23]$.

\subsection{Impervious Cover and Aquatic Buffer Zone}

Table 4 shows the impervious cover and aquatic buffer zones in each cascade-pond system catchment area.

Table 4. Impervious cover and aquatic buffer zone [1]

\begin{tabular}{|c|c|c|c|}
\hline Pond & Aquatic Buffer Zone & Imperviousness & Classification \\
\hline Kenanga & Low riparian cover $(<90 \%)$ & $22.40 \%$ & Impacted \\
\hline Agatis & Moderate riparian cover $(90-95 \%)$ & $76.90 \%$ & Heavily damaged \\
\hline Mahoni & Moderate riparian cover $(90-95 \%)$ & $44.20 \%$ & Non-supporting \\
\hline Puspa & Good riparian cover $(>95 \%)$ & $41.50 \%$ & Non-supporting \\
\hline Ulin & Good riparian cover $(>95 \%)$ & $39.30 \%$ & Non-supporting \\
\hline Salam & Good riparian cover $(>95 \%)$ & $36.20 \%$ & Non-supporting \\
\hline
\end{tabular}



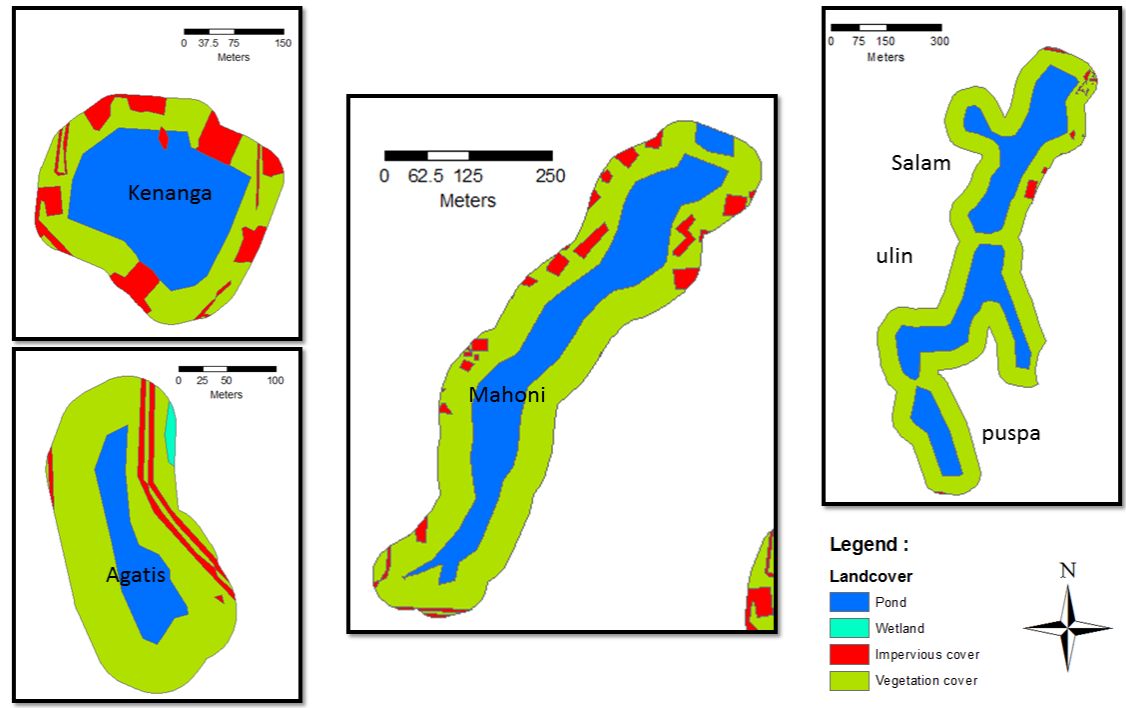

Fig. 4. Riparian buffer of Cascade-pond System

Most of cascade-pond system has moderate to good riparian cover except Kenanga (see Figure 4). Riparian cover has many ecological functions that support aquatic ecosystem. Losing riparian cover would impacted the macroinvertebrate indices. Some studies before shows that converting riparian cover into impervious cover may reducing macroinvertebrate indices. Riparian zone altered the macroinvertebrate composition particularly at low riparian cover zones [22,23].

\subsection{Relationship Between Macroinvertebrate Indices with Impervious Cover and Aquatic Buffer Zone}

Cross tabulation analysis shows that there is no specific pattern of relationship between macroinvertebrate indices and impervious cover. Only catchment that classified "nonsupporting" catchment reach the expected count for each tolerance categories (see Table 5). The Pearson Chi-square score is 112.096. Chi squared test calculation indicates that there is any relationship between macroinvertebrate and impervious cover because the score is greater than 9.49 for 0.05 probability with degree of freedom 4 . The asymptotic significance (2-sided) also shows that there is any relationship because the value is 0.000 which is smaller than 0.05 probability. Cross tabulation analysis for macroinvertebrate indices and aquatic buffer zone shows some specific pattern that may indicating the relationship between them (see Table 6). 56.2\% of macroinvertebrates was found at pond which has low riparian cover. On the other hands, $51 \%$ of moderate macroinvertebrate was found at pond that moderate riparian cover and $61.8 \%$ of sensitive macroinvertebrate was found at good riparian cover catchment. The Pearson Chi-square score is 142.096. Chi squared test calculation indicates that there is any relationship between macroinvertebrate and aquatic buffer zone because the score is greater than 9.49 for 0.05 probability with degree of freedom 4 . The asymptotic significance (2-sided) also shows that there is any relationship because the value is 0.000 which is smaller than 0.05 probability. 
Table 5. Crosstab option between macroinvertebrates indices and impervious cover

\begin{tabular}{|c|c|c|c|c|c|c|}
\hline & & & \multicolumn{3}{|c|}{ IC } & \multirow[t]{2}{*}{ Total } \\
\hline & & & $\begin{array}{c}\text { Heavily } \\
\text { damaged }\end{array}$ & $\begin{array}{c}\text { non- } \\
\text { supporting }\end{array}$ & Impacted & \\
\hline \multirow[t]{12}{*}{ Tolerance } & \multirow[t]{4}{*}{ tolerant } & Count & 27 & 221 & 49 & 297 \\
\hline & & Expected Count & & & & \\
\hline & & & 55.6 & 210.7 & 30.6 & 297.0 \\
\hline & & $\%$ within tolerance & $9.1 \%$ & $74.4 \%$ & $16.5 \%$ & $100.0 \%$ \\
\hline & \multirow[t]{4}{*}{ moderate } & Count & 52 & 50 & 0 & 102 \\
\hline & & Expected Count & & & & \\
\hline & & $\%$ within Tolerance & & & & \\
\hline & & & $51.0 \%$ & $49.0 \%$ & $0.0 \%$ & $100.0 \%$ \\
\hline & \multirow[t]{4}{*}{ sensitive } & Count & 10 & 66 & 0 & 76 \\
\hline & & Expected Count & & & & \\
\hline & & & 14.2 & 53.9 & 7.8 & 76.0 \\
\hline & & $\%$ within Tolerance & $13.2 \%$ & $86.8 \%$ & $0.0 \%$ & $100.0 \%$ \\
\hline \multirow{4}{*}{\multicolumn{2}{|c|}{ Total }} & Count & 89 & 337 & 49 & 475 \\
\hline & & Expected Count & & & & \\
\hline & & & & & & \\
\hline & & $\%$ within Tolerance & $18.7 \%$ & $70.9 \%$ & $10.3 \%$ & $100.0 \%$ \\
\hline
\end{tabular}

Table 6. Crosstab option between macroinvertebrates indices and aquatic buffer zones

\begin{tabular}{|c|c|c|c|c|c|c|}
\hline & & & \multicolumn{3}{|c|}{ Aquatic buffer zone } & \multirow[t]{2}{*}{ Total } \\
\hline & & & Low & Moderate & Good & \\
\hline \multirow[t]{9}{*}{ Tolerance } & \multirow[t]{3}{*}{ tolerant } & Count & 167 & 62 & 68 & 297 \\
\hline & & Expected Count & 108.8 & 85.0 & 103.2 & 297.0 \\
\hline & & $\%$ within tolerance & $56.2 \%$ & $20.9 \%$ & $22.9 \%$ & $100.0 \%$ \\
\hline & \multirow[t]{3}{*}{ moderate } & Count & 0 & 52 & 50 & 102 \\
\hline & & Expected Count & 37.4 & 29.2 & 35.4 & 102.0 \\
\hline & & $\%$ within Tolerance & $0.0 \%$ & $51.0 \%$ & $49.0 \%$ & $100.0 \%$ \\
\hline & \multirow[t]{3}{*}{ sensitive } & Count & 7 & 22 & 47 & 76 \\
\hline & & Expected Count & 27.8 & 21.8 & 26.4 & 76.0 \\
\hline & & $\%$ within Tolerance & $9.2 \%$ & $28.9 \%$ & $61.8 \%$ & $100.0 \%$ \\
\hline \multirow[t]{3}{*}{ Total } & & Count & 174 & 136 & 165 & 475 \\
\hline & & Expected Count & 174.0 & 136.0 & 165.0 & 475.0 \\
\hline & & $\%$ within Tolerance & $36.6 \%$ & $28.6 \%$ & $34.7 \%$ & $100.0 \%$ \\
\hline
\end{tabular}




\section{Conclusion}

The term of "end-of-pipe" at cascade-pond system at UI catchment affecting the macroinvertebrate indices. the distribution of macroinvertebrates indices is relatively getting better and healthier from upstream to downstream. Macroinvertebrate indices at cascade-pond system at UI catchment is also affected by aquatic buffer zone and impervious cover. Aquatic buffer zone has the most significant relationship than impervious cover because the Chi-squared value is greater.

\section{Acknowledgment}

The author would like to thank the financial support provided by Universitas Indonesia through the PITTA 2017 funding scheme under grant no. 857/UN2.R3.1/HKP.05.00/2017, managed by the Directorate for Research and Public Service, Universitas Indonesia and member of Hydraulics, Hydrology, and River Engineering, Department of Civil Engineering, Universitas Indonesia for helping the field survey. Special thanks to Drs. Wisnu Wardhana, M.Si. from Department of Biology, Universitas Indonesia for helping the identification of macroinvertebrates.

\section{References}

1. D. Sutjiningsih. Int. Jour. Tech. 1, 145 (2017)

2. T. R. Schueler, L. Fraley-McNeal, K. Cappiella. J. Hydrol. Eng. 14, 309 (2009)

3. H. Kim, H. Jeong, J. Leon, S. Bae. Water.8, 111 (2016)

4. T. J. Mackintosh, J. A. Davis, R. M. Thompson. Sc. Tot. Env. 536, 527 (2015)

5. R. Schiff, G. Benoit. J. Amr. Wat. Res. Ass. 43, 712 (2007)

6. M. N. Damanik-Ambarita, K. Lock, P. Boets, G. Everaert, T. H. T. Nguyen, M. A. E. Forio, P. L. S. Musonge, N. Suhareva, E. Bennetsen, D. Landuyt, L. DominguezGranda, P. L. M. Goethals. Iimnologica. 57, 27 (2016)

7. J. E. Helson, D. D. Williams. Ecol. Ind. 29, 167 (2013)

8. J. Xia, Y. Zhang, C. Zhao, S. E. Bunn. J. Hydrol. Eng. 19 (2014)

9. C. J. Goodnight. Trans. Amr. Micr. Soc. 92, 1 (1973)

10. E. Mylinski, W. Ginsburg. J. Amr. Wat. Wor. Ass. 69, 538 (1977)

11. L. Li, B. Zheng, L. Liu. Proc. Env. Sci. 2, 1510 (2010)

12. B. A. Markert, A. M. Breure, H. G. Zechmeister, Bioindicators \& Biomonitors (Elsevier, Oxford, 2003)

13. T. Alemneh, A. Ambelu., S. Bahrndorff, S. T. Mereta, C. Pertoldi, B. J. Zaitchik. Ecol. Ind. 73, 452 (2017)

14. W. J. Van de Bund, W. Goedkoop, R. K. Johnson. J. Nor. Amr. Benth. Soc. 41, 532 (1994)

15. J. B. Wallace, J. R. Webster. Ann. Rev. Ento. 41, 115 (1996) 
16. A. P. Covich, M. A. Palmer, T. A. Crowl. Bioscience. 49, 119 (1999)

17. T. J. Blakely, H. S. Eikass, J. S. Harding. Raff. Bul. Zoo. 62, 540 (2014)

18. Y. Zhang, D. Dudgeon, D. Cheng, W. Thoe, L. Fox, Z. Wang, J. H. W. Lee. Hydrobiol. 652, $71(2010)$

19. K. J. Collier, B. L. Clements. Hydrobiol. 664, 35 (2011)

20. B. Wang, D. Liu, S. Liu, Y. Zhang, D. Lu, L. Wang. Hydrobiol. 680, 39 (2012)

21. C. M. Lorion, B. P. Kennedy. Fresh. Biol. 54, 165 (2009)

22. A. B. Moraes, A. E. Wilhelm, T. Boelter, C. Stenert, U. W. Schulz, L. Maltchik. Environ. Monit. Assess. 186, 7063 (2014)

23. J. P. Duehr, M. J. Siepker, C. L. Pierce, T. M. Isenhart. Jour. Iowa. Acad. Sci. 1, 49 (2006)

24. D. Sutjiningsih, E. Anggraheni. The $12^{\text {th }}$ International Conference on Quality in Research (2011) 